\title{
A French perspective on the China-EU comprehensive agreement on investment: the proof of the pudding is in the eating
}

\section{Françoise Nicolas ${ }^{1}$ (D)}

Received: 14 April 2021 / Revised: 28 July 2021 / Accepted: 16 August 2021 /

Published online: 8 January 2022

(c) The Author(s), under exclusive licence to Springer-Verlag GmbH Germany, part of Springer Nature 2021

\begin{abstract}
The major objective of the China-EU CAI was to facilitate a rebalancing of the bilateral relationship by improving access for European companies to the Chinese market and leveling the playing field for them in China. While progress on the former is hard to deny, the situation is less rosy on the latter, and whether China will expeditiously implement its commitments remains an open question. France-one of the driving forces behind the deal—shares the European Commission's optimism and considers that the agreement represents a step forward and a sign of China's willingness to open up further.
\end{abstract}

After 7 years and some 35 rounds of talks, China and the EU concluded in principle the negotiations for a Comprehensive Agreement on Investment (CAI) on December 30, 2020, 1 day before the end of the German rotating presidency of the EU Council. The timing is certainly no coincidence: Chancellor Merkel had been pushing actively for the conclusion of the deal as a way of leaving her mark before passing on the baton to Portugal for the EU presidency (and ultimately stepping down as Chancellor of the Federal Republic of Germany). The full text of the Agreement was eventually disclosed by the EU Commission on January 22, 2021.

Both China and the EU have hailed an investment agreement between the two sides as a breakthrough (with Xi calling it a "balanced, high-level, and mutually beneficial" agreement), but whether this is indeed the case is a moot point.

Officially, the major objective of this sui generis agreement was to facilitate a rebalancing of the bilateral relationship by improving access for European companies to the Chinese market and leveling the playing field for them in China. From an EU perspective, while the gains on the former point are undeniable (albeit modest), there is more uncertainty on the latter. Moreover, although the agreement was

Françoise Nicolas

nicolas@ifri.org

1 Center for Asian Studies, Institut Francais Des Relations Internationales, Paris, France 
supposed to include provisions on investment protection, those are still missing. Lastly, the quality of China's commitments on sustainable development and labor standards is highly questionable.

\section{A diplomatic win for China?}

Clinching the deal has been a subject of controversy. The CAI's supporters argue that it was important that the EU closed the deal to demonstrate its ability to act autonomously (i.e., independently of the US), and stress that the requests from the EU were perfectly aligned with those of the USA. Critics, meanwhile, claim that the deal was closed in a hasty manner and offered a diplomatic victory to China while potentially driving a wedge between the EU and its US partner, as well as triggering tensions within the EU, with several "small" countries considering they were to some extent side-lined in the final stretch of the negotiation that was dominated by Germany and France. Which one of these views is right is anybody's guess, but there is no denying that the deal constitutes a win for China, diplomatically, if not economically. Indeed, it is no secret that President Xi Jinping did not want the EU and the US to team up and coordinate their responses towards China. With the conclusion of the negotiations a couple of weeks before President-elect Biden's inauguration, President Xi got exactly what he wanted. Moreover, the fact that the deal was signed in a context of rising CCP crackdowns in Xinjiang and Hong Kong does not send the right signal and can be easily (although dishonestly) interpreted as a sign of support.

The explanation for what is deemed by some as an ill-timed decision is primarily to be found in Germany. Chancellor Merkel must have acted under the pressure of some parts of the German industry (in particular the automotive sector, which has considerable interests in China and is keen to maintain good relations with Beijing). Still, not all German industrialists are on the same page. The BDI's position has shifted over the past few years (in particular since the highly publicized acquisition of Kuka robotics by China's Midea in 2016) towards more caution vis-à-vis China. German politics has also shifted toward a harder stance on China, and it is likely that Chancellor Merkel's successor will take up a different line on relations with Beijing.

As for France, the signing of the deal independently of the USA undoubtedly resonated with the call for strategic autonomy close to president Macron's heart. This may account for France's support to Germany although the former's economic interests in China cannot be compared to the latter's. Moreover, according to some analysts, president Macron may also have secured benefits for some particular companies with a heavy economic weight in France, such as Airbus,.

\section{The economic content of the deal}

The major objective of the China-EU CAI was to facilitate a rebalancing of the bilateral relationship by improving access for European companies to the Chinese market and leveling the playing field for them in China. In this respect, the agreement was 
to go beyond a standard bilateral investment treaty as it includes market access provisions. More generally, the point was to reduce ambiguity and discretion.

\section{A mixed picture}

While the CAI was supposed to be the first stand-alone investment agreement covering both market access and investment protection, it is not yet the case since the final text does not cover post-establishment nor investment protection issues. As a result, the existing bilateral investment treaties between China and 26 EU member states are not superseded by the new agreement. ${ }^{1}$ But the two parties agreed to set a rendez-vous clause and complete the negotiations on investment protection within two years of signing the CAI.

According to the Commission, China is deemed to have made commitments on various points of interest to the EU, and this is why EU officials assert that the agreement is "substantial" (a condition imposed by the EU to close a deal with China).

On market access, progress is hard to deny: A first important point is that China is bound by the liberalization decisions it made over the last 20 years, thus preventing backsliding on conditions of market access for EU companies. Moreover, several sectors are now open to European investors, such as R\&D in biological resources, telecommunication/cloud services, international maritime transport, or air transportrelated services. Also, several constraints imposed so far on European investors, such as quantitative restrictions, equity caps or joint venture requirements, are eliminated in a broader range of sectors (automotive, financial services, computer services, environmental services, or private hospitals in key Chinese cities, among others). A number of caveats are worth mentioning; however: liberalization commitments remain limited in agriculture, fisheries, mining, and energy; moreover, it is difficult to figure out whether all the commitments made really go beyond what China has already pledged to provide through its recent reforms on foreign investment.

On leveling the playing field, the picture is even less rosy: The major commitments relate to the discipline imposed on State-Owned-Enterprises (SOEs), transparency in subsidies, and the elimination of forced technology transfers, but China's track record on all these issues raises doubts as to its ability to turn these promises into reality.

Another widely praised point relates to the integration of environmental sustainability considerations in the bilateral investment relationship (with a reference to the implementation of the Paris Accord on climate change), as well as references to labor standards. The former addition is particularly noteworthy as this is the first time that China has agreed to such ambitious provisions with a trade partner. However, the parties only commit to facilitating and encouraging investment in environmentally or climate-friendly goods and services generally without further binding provisions.

As for the prohibition of forced labor, Beijing merely commits to "work towards the ratification of the ILO fundamental Conventions" ... and "shall make continued

\footnotetext{
${ }^{1}$ With the exception of Ireland, all EU member states have already concluded BITs with China.
} 
and sustained efforts on its own initiative to pursue ratification of the fundamental ILO Conventions No 29 and 105" (on the abolition of forced labor). Moreover, the commitment is in no way binding and there is no date for its implementation. Several analysts close to the Chinese leadership have clearly stated that China should not be expected to budge on this issue in the near future, particularly in so far as it pertains to policies put in place regarding Xinjiang. Beijing is thus unlikely to adhere to the ILO conventions any time soon.

\section{Reasons for concern}

Despite the apparently positive contributions resulting from the CAI for the EU, several sources of concern should not be underestimated, which result from the rather weak enforcement provisions or the lack of relevance of some provisions. The examples below are meant to be indicative of the potential difficulties arising from the implementation of the agreement.

With regard to forced technology transfers, for instance, it is a well-known fact that indirect measures are more frequently used by China. The provisions calling for a foreign company to operate as a joint venture with a domestic firm that it would not be able to control, and to which it would thus have to transfer technology, gradually disappeared after China joined the WTO. Yet, forced technology transfers persist, but they are no longer "compensated for" by any benefits. The transfers are obtained through indirect means or pressures that cannot be easily traced. They simply arise from how business is conducted in China and not from the implementation of formal legal rules. To be more specific, the problem lies with measures such as forced manufacturing or data localization in China rather than with formal requests for technology transfers. As a result, the commitment to drop the regulations on forced technology transfers is not really relevant.

Similarly, on SOES, the CAI seeks to discipline their behavior by requiring them to act in accordance with commercial considerations and not to discriminate in their purchases and sales of goods or services; but given the importance that SOEs play in China's economy, one may legitimately be doubtful of Beijing's ability (and willingness) to turn these commitments into reality. As stated in the Decisions of the 11th Party Congress' 3rd Plenum of China's Communist Party in 2013, the state and SOEs are to play a "dominant" role in the economy (which incidentally contradicts somehow the "decisive" role of the market in the same Decisions) and SOEs can thus be expected to remain major instruments of public policies.

The commitments made by China are as good as the dispute settlement mechanism which will ensure that the agreement is properly and faithfully implemented. On this point, the situation is still uncertain. An investor-state dispute settlement (ISDS) mechanism in the form of an investment court system favored by the EU was rejected by China. Although a major step forward lies in the establishment of a comprehensive state-to-state dispute settlement mechanism, there is a lack of clarity. In fact, there are several such mechanisms (and not a single one) dealing with different issues. More specifically, there will be a separate mechanism (working group) to follow the implementation of matters related to sustainable development, including on labor and climate. 
Lastly, the two parties agreed to complete the negotiations on investment protection and investment dispute settlement within 2 years of signing the CAI. This will be a test of their ability to stick to their words. French authorities and business groups give China the benefit of the doubt.

Despite these uncertainties, French business circles tend to be a priori positive towards the CAI, for the simple reason that the absence of an agreement could turn out to be costly for them, especially for companies that are heavily involved in China. As a result, they maintain a cautiously positive view while also stressing that the agreement falls short of their expectations with regards to several issues such as government procurement. An opinion piece published by the China-France committee, a group which gathers French companies operating in China, clearly states that China's promising move still needs to be confirmed. ${ }^{2}$

As for French authorities, they share the European Commission's optimism and consider that the agreement represents a step forward and a sign of China's willingness to open up further. While the Elysée sees the glass as being half full and praises Beijing for taking a step in the right direction, other political figures view it differently and doubt Beijing's ability to keep its words. For instance, a couple of days ahead of the signing of the agreement, France's junior minister for trade Franck Riester publicly criticized the deal over a lack of commitments on slave labor and a lack of investment protection. Beijing's commitment to ratify the ILO conventions on the prohibition of forced labor is undoubtedly the issue which aroused most controversies. Dissenting voices could be heard from several French political figures, such as Raphaël Glucksman, a French socialist member of the European Parliament, who questioned the sincerity of China's commitment to do their utmost to ratify the ILO's conventions on the prohibition of forced labor and strongly criticized the EC's decision to sign the deal.

\section{What next?}

The CAI still needs to be approved by the European Council and eventually ratified by the EU Parliament. The coming months will see a judicial review (legal scrubbing) of the text and, if things play out as planned, the ratification will take place at the earliest in 2022, but there is a non-negligible risk that this may not be the case due to disagreements on the forced labor issue.

Indeed, in mid-December 2020, the European Parliament issued a resolution on forced labor and the situation of the Uyghurs in the Xinjiang Uyghur Autonomous Region, ${ }^{3}$ strongly condemning the Chinese government-led system of forced labor and the exploitation of minority groups. The resolution is obviously in sharp contradiction with the CAI's a priori weak provisions on this issue and specifically calls on China to make "adequate commitments" on forced labor in the CAI, including the ratification of ILO Conventions 29 and 105. The recent flare up of tension between

\footnotetext{
${ }^{2}$ Lettre de la Chine hors les murs, January 20, 2021.

3 https://www.europarl.europa.eu/doceo/document/RC-9-2020-0432_EN.html
} 
the EU and China (in late March 2021), with the EU imposing sanctions on four Chinese officials for human rights abuses in Xinjiang, and Beijing responding with its own sanctions on Europeans, including Member of the European Parliament certainly does not bode well for the future of the deal and it remains to be seen whether the freezing of the ratification process decided by the European Parliament in May can be reversed.

According to EU officials, the EC hopes to use China's keen interest in having a deal (and in accessing the attractive EU market) to exert pressure and make Beijing budge, in particular on the forced labor issue. The recent outcome (in the EU's favor) of the dispute with Korea on a similar matter (non-compliance by Korea with commitments made on labor issues in the Korea-EU FTA) is given as an example of what can be achieved, but it sounds excessively optimistic to believe that China could be pressured in the same way as Korea was.

A more relevant point of reference may be with the recent trade dispute between Australia and China, which saw Beijing bullying Canberra and imposing trade sanctions after the latter asked for an independent investigation into the origin of the coronavirus. Given its size, it is easy for China to use its partners' state of dependence in a coercive way. More than the mere existence of interdependence, it is the asymmetrical nature of the interdependence that may be a source of vulnerability, and China is usually quick at weaponizing its upper hand and using economic coercion. The year to come will be a litmus test of the EC's ability to make use of the EU market as a lever, but these recent developments do not bode well for its chance of success.

Once (and if, and this has now become a big if) the agreement is indeed ratified, the next question is whether China will expeditiously implement its commitments and give up the discretionary approach which it has been using quite systematically in the past. Will it be the case? Only time will tell. Fortunately, the CAI is not the defining attribute of the EU-China relationship and there remains a wide range of instruments to monitor and shape the bilateral relation.

February 15, 2021 (revised July 28, 2021).

Publisher's note Springer Nature remains neutral with regard to jurisdictional claims in published maps and institutional affiliations. 